\title{
Оптимізація лікувально-профі.лактичної тактики при рубцевих дефектах внаслідок операцій на молочних залозах
}

\begin{abstract}
Мета роботи: удосконалити комплексне лікування пацієнтів з рубцевими дефектами молочних залоз після хірургічних втручань, обгрунтувати диференційований підхід до вибору лікувально-профілактичних заходів залежно від патогенезу утворення рубцевих дефектів та їх морфології.

Матеріали і методи. Вивчали результати лікувально-профілактичних заходів у трьох групах пацієнток: у першій групі (n=40) виконували інфільтрацію рубця розчином кортикостероїду та лідокаїну з використанням силіконового пластиру “Mepiform”(Швеція) та компресійної терапії; у другій групі (n=53) здійснювали хірургічне висічення з наступним введенням дипроспану в підрубцеву зону та накладання силіконового пластиру; у третій групі (контроль, n=45) проводили виключно висічення без профілактики повторного утворення дефектного рубця. За допомогою ультразвукового дермасканування в динаміці досліджувався розмір, об’єм і показники акустичної щільності рубця. Вимірювання акустичної щільності дерми здійснювали в ділянці розміщення рубця, як контроль вимірювали акустичну щільність дерми на здоровій контрлатеральній ділянці шкіри. При рубцях до 2 мм по ширині (ультрасонографічна оцінка) призначали консервативну терапію - пацієнтки першої групи. Контрольні УЗД-дослідження проводились через 1, 3, 9, 12 місяців після зняття швів. Виконували морфологічне та імуногістохімічне дослідження висічених рубців.

Результати досліджень та обговорення. Завдяки поєднаному застосуванню глюкокортикоїдів, компресійної пов’язки та силіконового пластиру у першій дослідній групі досягнуто зниження колагеногенезу, капілярогенезу і, як наслідок, унеможливлення відновлення дефектного рубця. Через 9-12 міс. у 67,5 \% утворились нормотрофічні рубці, а у 32,5 \% гіпотрофічні. Натомість у другій дослідній групі келоїдні рубці спостерігались у 28,9 \% випадків, гіпертрофічні - у 20 \%, гіпотрофічні у 11,1 \%, нормотрофічні у 40 \%. Отримані дані підтверджують, що хірургічне висічення як додаткова механічна травма не забезпечує ідеального вирішення ліквідації дефектного рубця навіть в поєднанні з профілактичними заходами. Наведений висновок випливає також і з результатів лікування контрольної групи (виключно висічення рубця): келоїдні рубці - у 46,7 \%, гіпертрофічні - у 11,1 \%, нормотрофічні - у $40 \%$
\end{abstract}

Ключові слова: келоїдні рубці; висічення рубцевих дефектів; комбіноване лікування рубця.

Постановка проблеми і аналіз останніх досліджень та публікацій. Рубець розвивається через заміщення власних тканин шкіри на сполучну і являє собою щільне утворення, яке виникає внаслідок регенерації тканин в результаті різних травматичних пошкоджень, де основним структурним елементом $\epsilon$ колагенові волокна $[1,2]$. Формування рубця $є$ природним наслідком поранення шкіри, а його морфологічні характеристики залежить від багатьох факторів, а саме: глибина та площа пошкодження шкіри, термін перебігу ранового процесу, зниження імунітету, мікроциркуляції та місцевої гемодинаміки, генетична схильність до посиленого утворення рубцевої тканини, наявність різної коморбідної патології та ін. [3, 4]. У світі, за даними різних авторів, від 4 до 10 \% пацієнтів схильні до утворення патологічних келоїдних і гіпертрофічних рубців після операційних втручань [5, 6].

Враховуючи високе різноманіття та поширеність патологій молочної залози, на даному органі часто виконуються первинні та повторні хірургічні інтервенції. Окрім того, щорічно у світі на 12 \% зростає кількість таких естетичних операцій, як ендопротезування молочних залоз, одномоментна мастопексія з ендопротезуванням, редукційна мамопластика [7]. Незважаючи на малоінвазивні хірургічні техніки, у значної кількості пацієнток розвиваються рубцеві дефекти, використання сучасних досягнень у їх лікуванні, а саме пневматичної компресії, фотодинамічної та метаболічної терапії, косметології, реконструктивно-пластичних операції не призвело до суттєвого покращення результатів $[8,9]$. Це спонукало науковців до розробки інноваційних принципів лікування пацієнтів з патологічними рубцями та активного впровадження лікувально-профілактичних заходів для уникнення повторних рецидивів нових дефектних рубців. До сьогодні не існує єдиного достовірного алгоритму заходів стосовно рубцевих дефектів молочних залоз та способів профілактики повторного патологічного рубцеутворення.

Мета роботи: удосконалення комплексного лікування пацієнтів з рубцевими дефектами молочних залоз після хірургічних втручань шляхом отримання оптимального лікувального ефекту на 
основі мінімізації травми органа, а також обгрунтування диференційованих підходів до вибору лікувально-профілактичних заходів залежно від патогенезу утворення рубцевих дефектів.

Матеріали і методи. У роботі вивчали результати проведення лікувально-профілактичних заходів у трьох групах пацієнток: у першій групі (n=40) виконували інфільтрацію рубця розчином кортикостероїду дипроспану та лідокаїну з використанням силіконового пластиру “Mepiform”(Швеція) та компресійної терапії; у другій групі (n=53) здійснювали хірургічне висічення з наступним введенням дипроспану в підрубцеву зону та накладання силіконового пластиру; у третій групі (контроль, $\mathrm{n}=45$ ) проводили виключно висічення без профілактики повторного утворення дефектного рубця. За співвідношенням різних морфологічних форм рубців групи були репрезентативними (табл. 1).

Таблиця 1. Розподіл типів рубцевих дефектів у групах до лікування

\begin{tabular}{||l|c|c|c||}
\hline & Перша група $(\mathrm{n}=40)$ & Друга група $(\mathrm{n}=53)$ & Група контролю $(\mathrm{n}=45)$ \\
\hline Келоїдні рубці & $17(42,5 \%)$ & $22(41,5 \%)$ & $21(46,7 \%)^{*}$ \\
\hline Гіпертрофічні рубці & $23(57,5 \%)$ & $31(58,5 \%)$ & $24(53,3 \%)^{*}$ \\
\hline \hline
\end{tabular}

Примітка: * - різниці між групами у жодному парному порівнянні не виявлено (p>0,05).

Ультразвукове дермасканування проводили за допомогою датчиків з частотою 22 МГц і 75 МГц (апарат Skinscanner DUB, Німеччина), що дозволяло візуалізувати епідерміс, дерму, підшкірну жирову клітковину, м'язові фасції, волосяні фолікули, просвіт судин шкіри. В роботі застосовували два режими візуалізації: в А-режимі отримували спектр амплітуд відбитих сигналів у кожній точці сканування, в В-режимі отримували 2-вимірне зображення сканованої ділянки на глибину 10 мм. В динаміці досліджувався розмір, об'єм і показники акустичної щільності рубця. Вимірювання акустичної щільності дерми здійснювали в ділянці розміщення рубця, як контроль вимірювали акустичну щільність дерми на здоровій контрлатеральній ділянці шкіри.

За допомогою ультрасонографії проводили моніторинг рубців, який полягав у скануванні дефектних рубців до лікування для вибору тактики (при рубцях до 2 мм по ширині застосовували консервативну терапію - пацієнтки першої групи) та після лікування, що дозволяло оцінити об'єм рубцевих змін і глибину поширення процесу в межах здорових тканин. При розмірах рубця більше 2 мм ультрасонографічно визначали та маркували межу між рубцевою тканиною та здоровою шкірою для подальшого економного висічення (у пацієнток другої групи).

Контрольні УЗД-дослідження проводили через 1, 3, 9 та 12 місяців після зняття швів. Групі пацієнток, яким застосовували малоінвазивний лікувально-профілактичний алгоритм, УЗДмоніторинг рубцевої ділянки здійснювали до лікування та через місяць після кожного внутрішньорубцевого введення препарату кортикостеро- їду. В кожному окремому випадку згідно з клінічними дослідженнями та УЗД визначали стан рубця та приймали рішення про продовження чи припинення лікування.

Виконували морфологічне та імуногістохімічне дослідження висічених рубців.

Результати досліджень та їх обговорення. Завдяки поєднаному застосуванню глюкокортикоїдів, компресійної пов'язки та силіконового пластиру в I досліджуваній групі (Д1) вдалося досягнути редукції посилення колагеногенезу, капілярогенезу і як наслідок унеможливлення відновлення дефектного рубця. Через 9-12 міс. після лікування жодного випадку формування келоїдного або гіпертрофічного рубця не спостерігали.

У свою чергу, у другій дослідній групі у жінок, в яких застосовували поєднання хірургічного висічення рубця з наступним введенням дипроспану в підрубцеву зону та накладання силіконового пластиру з компресійною терапією, констатовано наступні результати. Нормотрофічні рубці спостерігались у 33 жінок (62,2 \%), келоїдні рубці у 8 жінок (15,1\%), гіпертрофічні рубці у 3 жінок (5,7 \%) та гіпотрофічні у 9 жінок (17 \%). За результатами очевидно, що хірургічне висічення як ще одна механічна травма не забезпечує ідеального вирішення ліквідації дефектного рубця навіть у поєднанні з профілактичними заходами.

У третій групі в результаті застосування лише хірургічного висічення рубців станом на 9-12 місяці, що рецидив келоїдних рубців мав місце у 13 жінок (28,9\%), а гіпертрофічні рубці відновились у 5 жінок (11,1 \%) (рис. 1). 


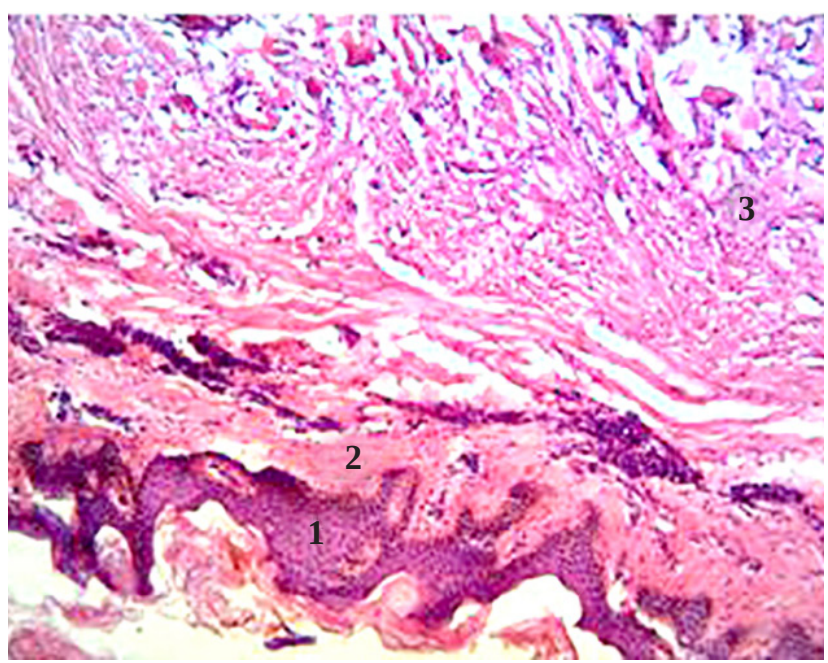

Рис. 1. Гістологічна картина видаленого келоїдного рубця молочної залози. Хаотичне розміщення щільних колагенових пучків. Фарбування толуїдиновим синім: 1 - епідерміс, 2 - нормальна структура сполучної тканини, 3 - келоїдний рубець.
Нормотрофічні рубці у ці ж контрольні проміжки часу встановлено у 18 жінок (40\%), а у 9 (20 \%) виявлено гіпотрофічні рубці при контрольному обстеженні (табл. 2).

Дані таблиці 2 підтверджують, що в результаті лікування в кожній з дослідних груп достовірно більше нормо- та гіпотрофічних рубців порівняно з контрольною групою. При цьому в першій групі число вказаних типів рубців достовірно переважало число другої групи. В контрольній групі рецидив дефектного рубцеутворення (гіпертрофічні та келоїдні рубці) з достовірно більшою кількістю дефектних рубців порівняно з другою групою. Також у другій групі значно частіше реєструвались нормотрофічні рубці, що було зумовлено економним висіченням попереднього рубця (під ультрасонографічним контролем - розріз виконувався на межі келоїдних волокон та здорової шкіри), відповідно, меншим натягом країв перед виконанням інтрадемального шва.

Таблиця 2. Розподіл морфологічних типів рубців через 9-12 місяців після лікування

\begin{tabular}{||l|c|c|c||}
\hline \hline & Перша група $(\mathrm{n}=40)$ & Друга група $(\mathrm{n}=53)$ & Група контролю $(\mathrm{n}=45)$ \\
\hline Нормотрофічні рубці & $27(67,5 \%)$ & $33(62,2 \%)^{\square}$ & $18(40 \%)^{* \circ}$ \\
\hline Гіпотрофічні & $13(32,5 \%)$ & $9(17 \%)^{\square}$ & $9(20 \%)^{*}$ \\
\hline Келоїдні рубці & 0 & $8(15,1 \%)^{\square}$ & $13(28,9 \%)^{* \circ}$ \\
\hline Гіпертрофічні рубці & 0 & $3(5,7 \%)^{\square}$ & $5(11,1 \%)^{* \circ}$ \\
\hline \hline
\end{tabular}

Примітка: * - різниця між першою групою і контрольною достовірна (“ксі»-квадрат; p<0,05);

○ - різниця між другою групою і контрольною достовірна (“ксі»-квадрат; p<0,05);

口 _ різниця між першою і другою дослідними групами достовірна (“ксі»-квадрат; p<0,05).

Висновки. 1. Застосування поєднання комплексу малоінвазивного лікування рубцевих дефектів та протирецидивних заходів ліквідувало проблему келоїдних та гіпертрофічних рубців у місці попереднього хірургічного втручання.

2. При застосуванні поєднання комплексу хірургічного лікування рубцевих дефектів та протирецидивних заходів вдалося знизити частоту келоїдних та гіпертрофічних рубців в місці попереднього хірургічного втручання на молочних залозах, однак не вдалося повністю ліквідувати патологічне рубцеутворення. У цій групі, як і в попередній, з'явилася група пацієнток із нормотрофічними та гіпотрофічними рубцями.

3. На відміну від двох дослідних груп, в конт- рольній групі пацієнток, яким проводили лише хірургічне висічення дефектного рубця, спостерігали рецидив патологічного рубцеутворення, що свідчить про недостатню ефективність даного способу боротьби з дефектними рубцями.

4. Індивідуалізований підхід до лікування рубцевих дефектів молочних залоз $є$ ефективним з огляду на попередження патологічного рубцеутворення.

Перспективи подальших досліджень. Розробка, дослідження та впровадження малоінвазивних методів ліквідації рубцевих дефектів молочних залоз без хірургічного висічення (незалежно від розміру рубця) є перспективним напрямком подальших досліджень.

\section{СПИСОК ЛІТЕРАТУРИ}

1. Gladstone H. B. Scar revision / H. B. Gladstone, D. Berg, M. McDonald // Dermatology research and practice. - 2010. P. 545796. doi: 10.1155/2010/545796.
2. Comparison of the histological morphology between normal skin and scar tissue / S. W. Yang, Z. J. Geng, K. Ma [et al.] // J. Huazhong Univ. Sci. Technolog. Med. Sci. - 2016. - Vol. 36 (2). - P. 265-269. 
3. Rabello F. B. Update on hypertrophic scar treatment / F. B. Rabello, C. D. Souza, J. A. Farina Júnior // Clinics. - 2014. - Vol. 69 (8). - P. 565-573.

4. Berman B. Keloids and hypertrophic scars: Pathophysiology, classification, and treatment / B. Berman, A. Maderal, B. Raphael // Dermatol. Surg. - 2017. - Vol. 43, Suppl. 1. - P. S3-S18.

5. Novel insights on understanding of keloid scar: Article review / W. Mari, S. G. Alsabri, N. Tabal // The Journal of the American College of Clinical Wound Specialists. - 2016. - Vol. 7 (1-3). - P. 1-7.

6. Ogawa R. Keloid and hypertrophic scars are the result of chronic inflammation in the reticular dermis / R. Ogawa // International
Journal of Molecular Sciences. - 2017. - Vol. 18 (3). - P. 606. 7. Nava M. B. A decision-making method for breast augmentation based on 25 years of practice / M. B. Nava, G. Catanuto, N. Rocco // Archives of Plastic Surgery. - 2018. Vol. 45 (2). - P. 196-203.

8. Current therapeutic approach to hypertrophic scars / Z. B. Mokos, A. Jović, L. Grgurević // Frontiers in Medicine. 2017. - Vol. 4. - P. 83.

9. Updated scar management practical guidelines: noninvasive and invasive measures. / S. Monstrey, E. Middelkoop, J. J. Vranckx // J. Plast. Reconstr. Aesthet. Surg. - 2014. Vol. 67 (8). - P. 1017-10125.

\section{REFERENCES}

1. Gladstone, H.B., Berg, D., \& McDonald, M. (2010). Scar revision. Dermatology Research and Practice, 2010, 545796. doi: 10.1155/2010/545796.

2. Yang, S.W., Geng, Z.J., Ma, K., Sun, X.Y., \& Fu, X.B. (2016). Comparison of the histological morphology between normal skin and scar tissue. J. Huazhong Univ. Sci. Technolog. Med. Sci., 36 (2), 265-269.

3. Rabello, F.B., Souza, C.D., \& Farina Júnior, J.A. (2014). Update on hypertrophic scar treatment. Clinics, 69 (8), 565-573.

4. Berman, B., Maderal, A., \& Raphael, B. (2017). Keloids and hypertrophic scars: pathophysiology, classification, and treatment. Dermatol. Surg., 43, 1, S3-S18.

5. Mari, W., Alsabri, S.G., Tabal, N., Younes, S., Sherif, A., \& Simman, R. (2016). Novel insights on understanding of keloid scar: Article review. The Journal of the American College of

Clinical Wound Specialists, 7 (1-3), 1-7.

6. Ogawa, R. (2017). Keloid and hypertrophic scars are the result of chronic inflammation in the reticular Dermis. International Journal of Molecular Sciences, 18 (3), 606.

7. Nava, M.B., Catanuto, G., \& Rocco, N. (2018). A decisionmaking method for breast augmentation based on 25 years of practice. Archives of Plastic Surgery, 45 (2), 196-203.

8. Mokos, Z.B., Jović, A., Grgurević, L., Dumić-Čule, I., Kostović, K., Čeović, R., \& Marinović, B. (2017). Current therapeutic approach to hypertrophic scars. Frontiers in Medicine, 4, 83.

9. Monstrey, S., Middelkoop, E., Vranckx, J.J., Bassetto, F., Ziegler, U.E., Meaume, S., \& Téot, L. (2014). Updated scar management practical guidelines: non-invasive and invasive measures. J. Plast. Reconstr. Aesthet. Surg., 67 (8), 1017-1025.

Отримано 15.11.2018

Електронна адреса для листування: doc@mamolog.lviv.ua

\section{S. I. SAVOLIUK ${ }^{1}$, H. O. RYBCHYNSKYY²}

P. Shupyk National Medical Academy of Postgraduate Education ${ }^{1}$, Kyiv Lviv State Regional Treatment and Diagnostic Oncology Center ${ }^{2}$

\section{OPTIMIZATION OF THERAPEUTIC AND PREVENTIVE TACTICS FOR SCAR DEFECTS AFTER BREAST SURGERY}

The aim of the work: to improve a complex treatment of patients with scar defects on the breast after surgical interventions and to substantiate the differentiated approach to the choice of therapeutic and prophylactic algorithm depending on the pathogenesis of the defective scar formation of morphology.

Materials and Methods. The results of therapeutic and prophylactic measures in three groups of patients were studied: in the group 1 $(n=40)$, the infiltration of the scar was performed with a solution of corticosteroid and lidocaine along with Mepiform (Sweden) silicone patch and compression therapy application; in the group $2(n=53)$, a surgical excision was performed followed by the introduction of diprospanone into the subcutaneous zone and the use of the silicone patch; in the group 3 (control, n=45), an excision was only performed without the prevention of the scar defect recurrence. With ultrasonic dermascanning in dynamics, the size, volume and acoustic scan density were measured. Acoustic density measurements of the dermis was carried out in the area of the scar location; as a control, the acoustic density of the dermis on a healthy contralateral area of the skin was measured. For scars less than 2 mm in width (ultrasonographic evaluation), a conservative therapy was used (patients of group I). Control ultrasound examinations were carried out in 1, 3, 9 and 12 months after the stitches were removed. Morphological and immunohistochemical study of the removed scars was carried out. Results and Discussion. Due to the combined use of glucocorticoids, compression bandages and silicone patches, in the first study group, a decrease in collagenogenesis, capillary degeneration and, consequently, prevention of the scar defect recurrence were achieved. 
In 9-12 months, the normotrophic scars were observed in $67.5 \%$, hypotrophic - in $32.5 \%$. However, in the group 2, keloid scars were detected in 28.9 \% of cases, hypertrophic - in $20 \%$, hypotrophic - in $11.1 \%$, normotrophic - in $40 \%$. The obtained data confirm that surgical excision, as an additional mechanical trauma, does not provide an ideal solution for the elimination of defective scar, even in combination with preventive measures. The above statement can also be concluded from the results of the control group treatment (scar excision only): keloid scars in $46.7 \%$, hypertrophic - in $11.1 \%$, normotrophic - in $40 \%$.

Key words: keloid scars; excision of defective scar; combined scar treatment.

\section{С. И. САВОЛЮК ${ }^{1}$, Г. О. РЫБЧИНСКИЙ}

Национальная медицинская академия последипломного образования имени П. Л. Шупика ${ }^{1}$

Львовский государственный онкологический региональный лечебно-диагностический центр²

\section{ОПТИМИЗАЦИЯ ЛЕЧЕБНО-ПРОФИЛАКТИЧЕСКОЙ ТАКТИКИ ПРИ РУБЦОВЫХ ДЕФЕКТАХ В РЕЗУЛЬТАТЕ ОПЕРАЦИЙ НА МОЛОЧНЫХ ЖЕЛЕЗАХ}

Цель работы: усовершенствовать комплексное лечение пациентов с рубцовыми дефектами молочных желез после хирургических вмешательств, обосновать дифференцированный подход к выбору лечебно-профилактических мероприятий в зависимости от патогенеза образования дефектных рубцов и их морфологии.

Материалы и методы. Изучали результаты лечебно-профилактических мероприятий в трех группах пациенток: в первой группе $(\mathrm{n}=40)$ выполняли инфильтрацию рубца раствором дипроспана и лидокаина с использованием силиконового пластыря “Mepiform”(Швеция) и компрессионной терапии; во второй группе (n=53) осуществляли хирургическое иссечение с последующим введением дипроспана в подрубцовую зону и наложением силиконового пластыря; в третьей группе (контроль, n=45) проводили исключительно иссечение без профилактики повторного образования дефектного рубца. С помощью ультразвукового дермасканирования в динамике исследовался размер, объем и показатели акустической плотности рубца. Измерения акустической плотности дермы осуществляли в области расположения рубца, в качестве контроля измеряли акустическую плотность дермы на здоровом контралатеральном участке кожи. При рубцах до 2 мм по ширине (ультрасонографическая оценка) применялась консервативная терапия - пациентки первой группы. Контрольные УЗИ-исследования проводились через 1, 3, 9, 12 месяцев после снятия швов. Выполняли морфологическое и иммуногистохимическое исследование иссеченных рубцов.

Результаты исследований и их обсуждение. Благодаря совместному применению глюкокортикоидов, компрессионной повязки и силиконового пластыря в первой исследуемой группе достигнуто снижение коллагеногенеза, капилярогенеза и, как следствие, устранение вероятности восстановления рубцового дефекта. Через 9-12 мес. у 67,5 \% пациенток образовались нормотрофические рубцы, а у 32,5 \% - гипотрофические. Зато во второй исследуемой группе келоидные рубцы наблюдались в 28,9 \% случаев, гипертрофические - в 20 \%, гипотрофические - в 11,1 \%, нормотрофические - в 40 \%. Полученные данные подтверждают, что хирургическое иссечение как дополнительная механическая травма не обеспечивает идеального решения ликвидации дефектного рубца даже в сочетании с профилактическими мерами. Приведенный вывод следует также и из результатов лечения контрольной группы (только иссечение рубца): келоидные рубцы образовались в 46,7 \% случаев, гипертрофические - в 11,1 \%, нормотрофические - в 40 \%.

Ключевые слова: келоидные рубцы; иссечение дефектного рубца; комбинированное лечение рубца. 